\title{
PCR detection of viral nucleic acid in fatal asthma: Is the lower respiratory tract a reservoir for common viruses?
}

\author{
Vasilija Macek $M D^{1}$, Azzeddine Dakhama $\mathrm{PhD}^{1}$, James C Hogg MD PhD ${ }^{1}$, \\ Francis HY Green $\mathrm{MD}^{2}$, Bruce K Rubin MEngr MD ${ }^{3}$, Richard G Hegele MD PhD ${ }^{1}$ \\ ${ }^{1}$ McDonald Research Laboratories, St Paul's Hospital, Vancouver, British Columbia; \\ ${ }^{2}$ Department of Pathology, University of Calgary, Calgary, Alberta; and ${ }^{3}$ Departments of \\ Pediatrics, Medicine, Physiology and Pharmacology, Wake Forest University School of \\ Medicine, Winston-Salem, North Carolina
}

V Macek, A Dakhama, JC Hogg, FHY Green, BK Rubin, RG Hegele. PCR detection of viral nucleic acid in fatal asthma: Is the lower respiratory tract a reservoir for common viruses? Can Respir J 1999;6(1):37-43.

BACKGROUND: There is indirect evidence implicating viral respiratory tract infections in the pathogenesis of fatal asthma. However, it is unknown whether viruses are present within the lower respiratory tract in fatal asthma.

OBJECTIVES: To apply a nine-virus polymerase chain reaction (PCR) panel to postmortem specimens of lower airway secretions and compare the prevalence of viral nucleic acid among patients who died of asthma, asthmatic patients who died of other causes and persons who died without lung disease.

PATIENTS AND METHODS: Postmortem specimens of lower airway secretions from patients who died of asthma (fatal asthma $[\mathrm{n}=10]$ ), asthmatic patients who died of other causes $(n=4)$ and nonasthma controls $(n=6)$ underwent PCR for nine common respiratory viruses. The prevalence of each virus was compared among the three groups.

RESULTS: PCR was positive for at least one virus in 19 of 20 cases, and multiple viruses were detected in 14 of 20 cases. The prevalence of each virus was similar in the three groups studied.

CONCLUSIONS: In fatal asthma, lower airway secretions do not show a specific pattern of viral nucleic acid. Intriguingly, these results suggest that the lower respiratory tract may act as a potential reservoir for common respiratory viruses.

Key Words: Fatal asthma, Polymerase chain reaction, Respiratory viruses

Détection par PCR d'acide nucléique viral dans l'asthme fatal : les voies respiratoires inférieures sont-elles un réservoir pour les virus courants?

HISTORIQUE : Des preuves indirectes démontrent que les infections virales des voies respiratoires sont impliquées dans la pathogenèse de l'asthme fatal. Cependant, la présence de ces virus à l'intérieur des voies respiratoires inférieures, pour ce qui est de l'asthme fatal, n'a pas été déterminée.

OBJECTIFS : Appliquer une amplification en chaîne par polymérase (PCR) d'une batterie de 9 virus à des spécimens post-

voir page suivante

Correspondence and reprints: Dr Richard G Hegele, McDonald Research Laboratories, St Paul's Hospital, 1081 Burrard Street, Vancouver, British Columbia V6Z 1Y6. Telephone 604-631-5346, fax 604-631-5351, e-mail rhegele@ prl.pulmonary.ubc.ca 
mortem de sécrétions des voies respiratoires inférieures et comparer la prévalence d'acide nucléique viral chez des patients décédés d'asthme, des patients asthmatiques décédés d'autres causes et des personnes décédées sans maladie pulmonaire.

PATIENTS ET MÉTHODES : Les spécimens postmortem de sécrétions des voies respiratoires inférieures de patients décédés d'asthme (asthme fatal $[\mathrm{n}=10]$ ), des patients asthmatiques décédés d'autres causes $(n=4)$ et des témoins non asthmatiques $(n=6)$ ont subi une PCR pour 9 virus respiratoires courants. La prévalence de chaque virus a été comparée chez les trois groupes.

RÉSULTATS : La PCR était positive pour au moins 1 virus chez 19 des 20 cas, et des virus multiples ont été décelés dans 14 des 20 cas. La prévalence de chaque virus était similaire dans les trois groupes étudiés.

CONCLUSIONS : Dans l'asthme fatal, les sécrétions des voies respiratoires inférieures ne révèlent pas de schéma spécifique d'acide nucléique viral. Chose curieuse, ces résultats laissent à penser que les voies respiratoires inférieures pourraient servir de réservoir aux virus respiratoires courants.
$\mathrm{V}$ iral respiratory tract infections have been implicated in the initiation of acute exacerbations of asthma based on clinical history, serology and analysis of specimens obtained from the upper respiratory tract (1-3). Human rhinovirus (HRV), the most common cause of viral upper respiratory tract infection, is reported to produce prolonged eosinophilic infiltration of the bronchial epithelium in both atopic asthmatics and in nonatopic, nonasthmatic individuals (4). Experimental HRV infections result in a long-lasting, excessive airway response to methacholine challenge in asthmatic subjects (5). The mechanisms of these virus-induced changes in lung structure and function may involve the extension of HRV infection from the nasopharynx to the lower respiratory tract (6). Although the potential role of viral lower respiratory tract infections in the pathogenesis of asthma is an area of considerable interest (7), there is only indirect evidence that such infections can occur. For example, in a recent study of asthmatic patients who died suddenly (8), the authors reported that the airway mucosa of patients contained large numbers of activated, cytotoxic CD8+ T lymphocytes, consistent with an antiviral host-immune response (9). However, it remains unclear whether respiratory viruses are present within the lower respiratory tract in fatal asthma, related in part to the limitations of viral culture of postmortem specimens.

The development of protocols based on the polymerase chain reaction (PCR) has provided a highly sensitive approach to detect nucleic acid sequences from common respiratory viruses in clinical specimens (10-14). Our laboratory previously reported a three-virus PCR panel (14) that established that PCR had over $90 \%$ sensitivity to viral culture of clinical respiratory specimens and was especially useful for detecting fastidious RNA pathogens such as HRV, respiratory syncytial virus (RSV), and parainfluenza virus (PIV). We have since expanded our PCR panel to test for nine common respiratory viruses, and have recently used this panel to document viral nucleic acid in surgically resected lung specimens (15).

The purpose of this study was to apply the nine-virus PCR panel to postmortem specimens of lower airway secretions, and compare the prevalence of viral nucleic acid among patients who died of asthma, asthmatic patients who died of other causes and persons who died without lung disease. The pathogens selected for the PCR panel (HRV, RSV, influenza viruses A, B and C, coronaviruses 229E and OC43, PIV and adenovirus) were based on previous reports of viral-induced acute exacerbations of asthma in children and adults $(1,2)$. Frozen, unfixed intraluminal contents from the lower airways were analyzed to avoid potential pitfalls of contamination of specimens by any viruses present in the upper respiratory tract and the limitations of using paraffinembedded tissues for organic RNA extraction, reverse transcription and PCR amplification (16).

\section{PATIENTS AND METHODS}

Autopsy cases: The 20 autopsy cases examined were selected from the Canadian Prairie Provinces Asthma Study, from postmortem examinations carried out between November 1991 and October 1995. This study included 34 centres located in the provinces of Alberta, Saskatchewan and Manitoba, where pathologists agreed in advance to obtain the specimens by using kits that had been prepackaged and located at each site. The kits contained disposable plastic transfer pipettes (Baxter Scientific Products) for the suctioning of airway intraluminal contents, centrifuge tubes with screwtop caps containing $15 \mathrm{~mL}$ of paraffin oil in which to store the specimens, and plastic bags to protect the tubes from environmental contamination.

The autopsy component was part of a larger case-control study designed to identify the cause(s) of the high death rate from asthma in the Canadian Prairie provinces (17). The present study was based on 10 cases where death was attributed to asthma (fatal asthma group), four asthmatic patients who died of other causes (nonfatal asthma group) and six nonasthmatic individuals in whom death was not related to lung disease (nonasthma control group). The histories of all 20 deaths are briefly summarized in Table 1 . The cigarette smoking history and other demographic information were obtained by a questionnaire that was answered by the next of kin.

Specimens - Airway secretions: Specimens were obtained by suctioning the airways of the left lung after it had been removed from the thorax, before inflation, fixation and sectioning. Clean, disposable plastic transfer pipettes were used to suction the intraluminal contents of the lower airways and immerse these contents within paraffin oil. Frozen specimens were shipped by courier to the central bank at the University of Calgary, Calgary, Alberta, where they were stored at $-70^{\circ} \mathrm{C}$. The case material selected for study was forwarded on dry ice to the University of British Columbia Pulmonary Research Laboratory, Vancouver, British Columbia for PCR analysis. Specimens were coded such that the personnel performing PCR were not aware of any clinical information re- 
TABLE 1

Clinical information for $\mathbf{2 0}$ cases studied for viral nucleic acid content of the lower airway secretions

\begin{tabular}{|c|c|c|c|c|}
\hline Case number & Sex/age (years) & Smoking status & History & Asthma severity* \\
\hline \multicolumn{5}{|l|}{ Fatal asthma } \\
\hline 1 & Male/43 & Nonsmoker & $\begin{array}{l}\text { Known asthmatic also suffered from myasthenia gravis. Used } \\
\text { oxygen mask with nebulizer (salbutamol, Ventolin, Glaxo } \\
\text { Wellcome). Found unresponsive lying prone on floor wearing } \\
\text { nebulizer mask }\end{array}$ & Moderate \\
\hline 2 & Female/43 & Smoker & $\begin{array}{l}\text { Known asthmatic. Called ambulance. Found unconscious lying } \\
\text { prone on floor in cardiac arrest }\end{array}$ & Mild \\
\hline 3 & Female/21 & Nonsmoker & Respiratory failure secondary to acute exacerbation of asthma & Severe \\
\hline 4 & Male/51 & Smoker & $\begin{array}{l}\text { Asthma. Acute bronchitis and bronchopneumonia. Histological } \\
\text { evidence of aspiration. Barotrauma. Emphysema }\end{array}$ & Moderate \\
\hline 5 & Male/51 & Smoker & $\begin{array}{l}\text { Treated and discharged from hospital day before death from } \\
\text { asthma attack }\end{array}$ & Severe \\
\hline 6 & Male/43 & Nonsmoker & $\begin{array}{l}\text { Long history of asthma. Patient called ambulance for } \\
\text { assistance. Found lying face down and cyanotic, and showed } \\
\text { fixed dilated pupils }\end{array}$ & Severe \\
\hline 7 & Male/18 & Nonsmoker & $\begin{array}{l}\text { History of asthma. Collapsed in parking lot while getting more } \\
\text { medication }\end{array}$ & Severe \\
\hline 8 & Female/19 & Nonsmoker & Anoxic encephalopathy secondary to acute asthma attack & Severe \\
\hline 9 & Male/19 & Smoker & $\begin{array}{l}\text { Experienced shortness of breath while travelling in car. } \\
\text { Attempted to use salbutamol inhaler before collapsing }\end{array}$ & Mild \\
\hline 10 & Female/37 & Smoker & $\begin{array}{l}\text { Severe asthma and bipolar affective disorder. Found dead in } \\
\text { bed with inhaler beside her }\end{array}$ & Moderate \\
\hline \multicolumn{5}{|c|}{ Nonfatal asthma } \\
\hline 11 & Female/41 & Smoker & $\begin{array}{l}\text { History of asthma and hypothyroidism. Died of coronary } \\
\text { atherosclerosis }\end{array}$ & Moderate \\
\hline 12 & Female/39 & Smoker & $\begin{array}{l}\text { Acute salicylate toxicity. Severe asthma and chronic obstructive } \\
\text { pulmonary disease }\end{array}$ & Moderate \\
\hline 13 & Female/44 & Smoker & $\begin{array}{l}\text { Known asthmatic. Died of bacterial peritonitis due to diverticular } \\
\text { disease }\end{array}$ & Mild \\
\hline 14 & Female/38 & Smoker & Known asthmatic. Sudden death due to coronary artery disease & Mild \\
\hline \multicolumn{5}{|c|}{ Nonasthma controls } \\
\hline 15 & Male/57 & Smoker & $\begin{array}{l}\text { Cardiac arrest in ambulance. Died of occlusive coronary } \\
\text { atherosclerosis }\end{array}$ & $\mathrm{N} / \mathrm{A}$ \\
\hline 16 & Male/50 & Smoker & $\begin{array}{l}\text { Found supine in bed. Died of coronary atherosclerosis with } \\
\text { thrombosis }\end{array}$ & $\mathrm{N} / \mathrm{A}$ \\
\hline 17 & Male/42 & Smoker & $\begin{array}{l}\text { Apneic and pulseless on nursing rounds. Died of ischemic heart } \\
\text { disease and acute pulmonary edema }\end{array}$ & $\mathrm{N} / \mathrm{A}$ \\
\hline 18 & Female/42 & Smoker & $\begin{array}{l}\text { Sudden death due to primary dissecting aneurysm of left } \\
\text { anterior descending coronary artery }\end{array}$ & $\mathrm{N} / \mathrm{A}$ \\
\hline 19 & Female/50 & Nonsmoker & Malignant epithelial angiosarcoma & $\mathrm{N} / \mathrm{A}$ \\
\hline 20 & Male/33 & Smoker & $\begin{array}{l}\text { Sudden death due to subarachnoid hemorrhage from } \\
\text { spontaneous rupture of a cerebral aneurysm }\end{array}$ & $\mathrm{N} / \mathrm{A}$ \\
\hline
\end{tabular}

${ }^{*}$ Assessed histologically. N/A Not applicable

lated to the case material. This code was broken after the PCR analysis was completed and the results had been returned to Calgary.

Lung pathology: Following removal of the airway secretions, the left lungs were fixed by a combination of vascular and airway perfusion at controlled pressures with $2.5 \%$ glutaraldehyde. A total of 27 blocks of airway were sampled from upper and lower lobes to include representative samples of airways of all sizes. Histological sections were routinely stained with hematoxylin and eosin, Verhoeff's elastic trichrome and Alcian Blue (pH 2.5)/periodic acid Schiff. Asthma was diagnosed when a majority of characteristic histological features were present including intraluminal mucous exudate, thickening of the basement membrane, lym- phocytic and eosinophilic infiltrates in the airway wall, mucous gland enlargement and hypertrophy of the bronchial smooth muscle (18). For each patient, the overall severity of the asthma was graded as mild, moderate or severe (Table 1). The airways and lung parenchyma were also examined for histological evidence of viral, bacterial or fungal infection.

Viral detection - Nucleic acid extraction and preparation of PCR controls: Total RNA was extracted from the samples of airway intraluminal contents using a commercial reagent, Trizol (Gibco BRL) according to manufacturer's instructions. DNA was extracted by QIAamp Tissue Kit (Qiagen $\mathrm{GmbH}$, Hilden, Germany) after overnight digestion of specimens at $55^{\circ} \mathrm{C}$ with $0.1 \mathrm{mg} / \mathrm{mL}$ proteinase $\mathrm{K}$ in $100 \mathrm{mM}$ sodium chloride; 10 mM Tris, $\mathrm{pH}$ 8; 25 mM EDTA, pH 8; $0.5 \%$ 
TABLE 2

Oligonucleotide primers and probes

\begin{tabular}{|c|c|c|c|}
\hline Target & Specific flanking primers and probes & Gene & $\begin{array}{c}\text { Product size } \\
\text { (basepairs) }\end{array}$ \\
\hline Human rhinovirus (HRV) & $\begin{array}{l}\text { Antisense 5' CGGACACCCAAAGTAG 3' } \\
\text { Sense 5' GCACTTCTGTTTCCCC 3' } \\
\text { Probe 5' GCATTCAGGGGCCGGAG 3' }\end{array}$ & $\begin{array}{c}5^{\prime} \text { noncoding region of } \\
\text { HRV type 1B }\end{array}$ & 380 \\
\hline Respiratory syncytial virus & $\begin{array}{l}\text { Antisense 5' GCGATGTCTAGGTTAGGAAGAA 3' } \\
\text { Sense 5' GCTTCCTTGGGTAGTAAGCCT 3' } \\
\text { Probe 5' TAGCTCCAGAATAGTAAGCCT 3' }\end{array}$ & Nucleocapsid & 410 \\
\hline Influenza B & $\begin{array}{l}\text { Antisense 5' AGCGTTCCTAGTTTTACTTGCAT 3' } \\
\text { Sense 5' GAAAAATTACACTGTTGGTTCGG 3' } \\
\text { Probe 5' TTCTAGCTGAGAGAAAAATGAGAAGATGT 3' }\end{array}$ & Matrix protein & 365 \\
\hline Influenza C & $\begin{array}{l}\text { Antisense 5' GCCAGTAATACCAGCAATCTCG 3' } \\
\text { Sense 5' CCCTAATGTCTTGGAGAAGCCAC 3' } \\
\text { Probe 5' TCCGAATAGGAACAATCACAGCTTGGTT 3' }\end{array}$ & Matrix protein & 425 \\
\hline Coronavirus 229E & $\begin{array}{l}\text { Antisense 5' TGCACTAGGGTTAATGAAGAGG 3' } \\
\text { Sense 5' GGTACTCCTAAGCCTTCTCG 3' } \\
\text { Probe 5' GACTATCAAACAGCATAGCAGC 3' }\end{array}$ & Nucleocapsid & 370 \\
\hline Coronavirus OC43 & $\begin{array}{l}\text { Antisense 5' TGCAAAGATGGGGAACTGTGGG 3' } \\
\text { Sense 5' AGGAAGGTCTGCTCCTAATTCC 3' } \\
\text { Probe 5' GTTCTGGCAAAACTTGGCAAGG 3' }\end{array}$ & Nucleocapsid & 450 \\
\hline Parainfluenza virus & $\begin{array}{c}\text { Antisense 5' TAGCAGTATTGAAGTTGGCA 3' } \\
\text { Sense 5' AGACCTCAATACCAACAACTA 3' } \\
\text { Probe 5' AAAATTCCAAAACAGACCGGC 3' }\end{array}$ & $\begin{array}{l}\text { F gene } 5 \text { ' nontranslated } \\
\text { region }\end{array}$ & 205 \\
\hline Adenovirus & $\begin{array}{l}\text { Outer primers } \\
\text { Antisense 5' CAGCACGCCGCGGATGTCAAAGT 3' } \\
\text { Sense 5' GCCGCAGTGGTCTTACATGCACATC 3' } \\
\text { Nested primers } \\
\text { Antisense 5' TTGTACGAGTACGCGGTATCCTCGCGGTC 3' } \\
\text { Sense 5' GCCACCGAGACGTACTTCAGCCTG 3' }\end{array}$ & Hexon & 300 \\
\hline Human gene & $\begin{array}{l}\text { Antisense 5' CCCATCACCATCTTCCAG 3' } \\
\text { Sense 5' ATGACCTTGCCCACAGCC 3' } \\
\text { Probe 5' TCACCACCATGGAGAAGG 3' }\end{array}$ & $\begin{array}{l}\text { Glycerol-3-phosphate } \\
\text { dehydrogenase }\end{array}$ & 445 \\
\hline
\end{tabular}

sodium dodecyl sulphate (SDS) (Sigma Chemical Company, Missouri).

Virus-infected cell cultures served as positive controls for the PCR panel while uninfected cell cultures served as negative controls. The pathogens used in these controls were obtained from the American Type Culture Collection (ATCC, Maryland): HRV type 1B, RSV long strain type A, influenza $\mathrm{A} / \mathrm{Weiss} / 43$, influenza $\mathrm{B} / \mathrm{Lee} / 40$, influenza C/Taylor 1233/47, coronaviruses subtypes 229E and OC43, PIV type 3/C243 and adenovirus serotype 2. HRV was cultured on MRC-5 (ATCC) cell monolayers in Eagle's basal medium containing $5 \%$ fetal bovine serum (FBS) (Gibco BRL) and gentamicin $50 \mu \mathrm{g} / \mathrm{mL}$ (Gibco BRL). RSV was cultured on HEp-2 (ATCC) cell monolayers in minimal essential medium (MEM) (Gibco BRL) supplemented with 5\% FBS and gentamicin. The influenza viruses, coronaviruses and PIV were cultured on MK-2 monkey kidney cell monolayers in medium 199 (Gibco BRL) supplemented with 1\% horse serum (Hyclone, Utah) and gentamicin, with $0.01 \%$ trypsin (Gibco BRL) added to influenza cultures. Adenovirus type 2 was cultured on monolayers of A549 cells in MEM with 5\% FBS and gentamicin.
Reverse transcription: RNA samples (median \pm SE: $15 \pm 2 \mu \mathrm{g}$ total RNA, performed in duplicate) underwent reverse transcription at $37^{\circ} \mathrm{C}$ for $1 \mathrm{~h}$ in a $50 \mu \mathrm{L}$ reaction mixture consisting of $10 \mathrm{mM}$ Tris-hydrochloric acid (HCL), $\mathrm{pH}$ 8.3, $50 \mathrm{mM}$ potassium chloride, $5 \mathrm{mM}$ magnesium chloride, $50 \mu \mathrm{M}$ each of deoxynucleotide triphosphates (dNTPs), 50 units of RNase inhibitor (Pharmacia), $5 \mu \mathrm{g}$ of random hexamers (Pharmacia) and 250 units of cloned Moloney murine leukemia virus reverse transcriptase (Gibco BRL). After this incubation, the reverse transcriptase was inactivated by heating the reaction mixture to $95^{\circ} \mathrm{C}$ for 5 mins.

PCR amplification: Five $\mu \mathrm{L}$ of the cDNA product from the reverse transcription reaction was used in a $50 \mu \mathrm{L}$ PCR reaction mixture that consisted of $10 \mathrm{mM}$ Tris-hydrochloric acid, $\mathrm{pH}$ 8.3, $50 \mathrm{mM}$ potassium chloride, $2.5 \mathrm{mM}$ magnesium chloride, $50 \mu \mathrm{M}$ each of dNTPs, 1.5 units of Taq DNA polymerase (Gibco BRL) and 50 pmol each of pathogenspecific, flanking primers (Table 2). Samples underwent denaturation at $94^{\circ} \mathrm{C}$ for 4 mins, followed by 35 cycles of amplification in a thermal Robocycler-40 (Stratagene, California); each cycle consisted of denaturation at $94^{\circ} \mathrm{C}$ for $1 \mathrm{~min}$, annealing at $55^{\circ} \mathrm{C}$ for $1 \mathrm{~min}$ and extension at $72^{\circ} \mathrm{C}$ for 
1.5 mins (8 mins for last cycle). After amplification, the PCR products underwent electrophoresis on ethidium bromidestained, $1.5 \%$ agarose gels and were visualized under ultraviolet light. For nested PCR (adenovirus), $2 \mu \mathrm{L}$ of the initial PCR products were reamplified with the nested primers, in $50 \mu \mathrm{L}$ of the PCR reaction mixture. The resulting products of nested PCR underwent electrophoresis on 2\% agarose gels and were photographed under ultraviolet light using Polaroid 667 Professional Print Film (Massachusetts).

Southern blotting, filter hybridization and autoradiography: After Southern transfer onto Hybond-N nylon membranes (Amersham, Illinois) and cross-linking under ultraviolet light, PCR products were hybridized with the appropriate pathogen-specific oligonucleotide probe, which was end-labelled with $\left(\gamma-{ }^{32} \mathrm{P}\right)$ ATP using the T4 polynucleotide kinase reaction (Gibco BRL) following the manufacturer's instructions. Filter hybridization was carried out in a hybridization oven (Hybaid, Middlesex, England) at $65^{\circ} \mathrm{C}$ for $18 \mathrm{~h}$ in a solution consisting of six times standard saline citrate (SSC) ( $0.9 \mathrm{M}$ sodium chloride, $0.09 \mathrm{M}$ sodium citrate, $\mathrm{pH}$ 7.0), five times Denhardt's solution (0.1\% Ficoll 400, $0.1 \%$ bovine serum albumin [fraction $\mathrm{V}$ ], $0.1 \%$ polyvinylpyrrolidone), $0.5 \%$ SDS, and $100 \mu \mathrm{g} / \mathrm{mL}$ fragmented salmon sperm DNA. After hybridization, membranes were washed in six times SSC, three times 5 mins at room temperature and $30 \mathrm{mins}$ at $65^{\circ} \mathrm{C}$, before exposure to Kodak xray film. The films were exposed for up to four days.

Specific primers and probes for the positive controls were synthesized with an automated DNA synthesizer (University of Calgary). Previously published specific primers and probes were taken for all the viruses (10-14) with the exception of influenza $\mathrm{C}$, for which specific primers and probe of a sequence of the viral matrix protein gene were designed, based on results of a Genbank analysis that showed a lack of homology to published sequences from other micro-organisms or from primates. The oligonucleotides used to test for HRV could also detect other picornaviruses (11), and the oligonucleotides used for adenovirus PCR were chosen based on sequence homology between 47 serotypes of human adenovirus (13).

PCR quality assurance: PCR experiments were performed in duplicate to ensure reproducibility of results. In addition, to ensure that the RNA nucleic acid extraction procedure yielded specimens that did not contain PCR inhibitors, specimens underwent reverse transcriptase-PCR for a constitutively expressed gene, glycerol-3-phosphate dehydrogenase (GAPDH), using the flanking oligonucleotide primers and internal probe listed in Table 2. To determine whether the paraffin oil used to store airway secretions was contaminated by nucleic acid, a sham RNA extraction procedure was performed on an aliquot of paraffin oil alone or after blowing room air from a plastic pipette into the oil (environmental control). A PCR result was considered positive when an unequivocal band of predicted size was seen on autoradiographs or, for adenovirus nested PCR, on ethidium bromide-stained agarose gels in the presence of appropriate results for known positive and negative cell culture control specimens.

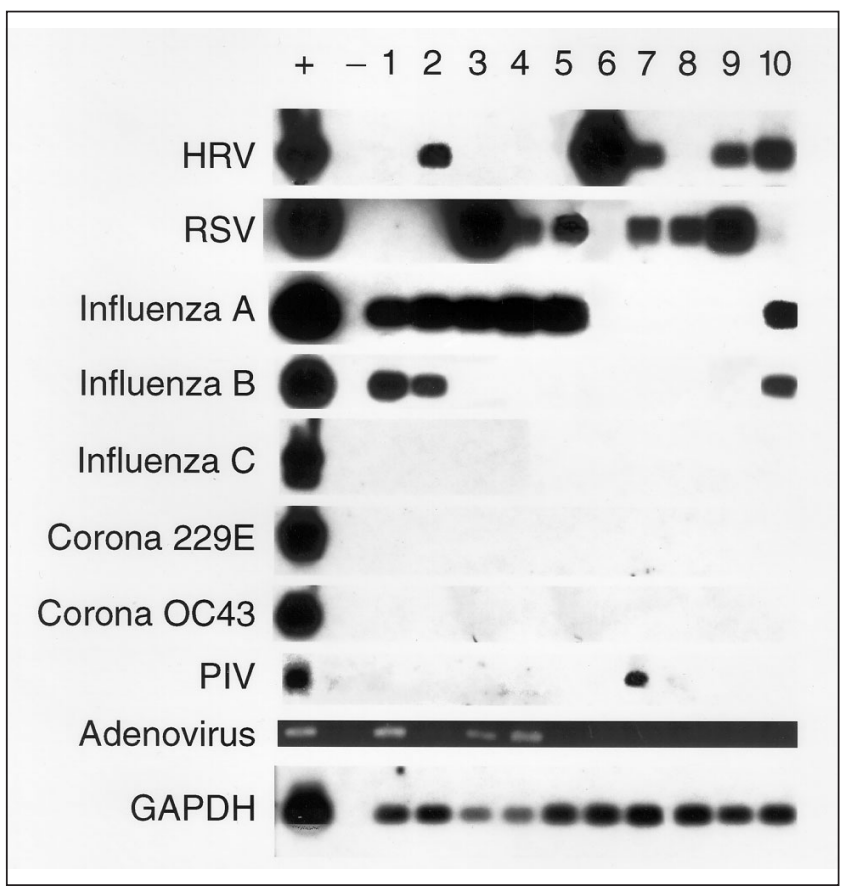

Figure 1) Polymerase chain reaction findings from nucleic acid extracted from lower respiratory secretions of four cases of fatal asthma (lanes 1,4,5,9), two case of nonfatal asthma (lanes 6,10) and four nonasthma controls (lanes 2,3,7,8), together with positive (+) and negative (-) cell culture control specimens. Note the presence of a positive signal from at least one virus in each subject, while the positive and negative controls (including the constitutively expressed constitutively-expressed gene, glycerol-3-phosphate dehydrogenase [GAPDH] gene) yielded predicted results. HRV Human rhinovirus; PIV Parainfluenza virus; RSV Respiratory syncytial virus

Statistical analysis: Fisher's exact test was used to compare the proportion of subjects with positive PCR results for each of the viruses tested among the three groups. ANOVA was used to evaluate both the relationship between the number of viruses identified within a specimen and the physical and transport properties of the lower airway secretions. For all analyses, $\mathrm{P}<0.05$ was considered to be statistically significant.

\section{RESULTS}

Figure 1 shows the results of 10 specimens of intraluminal airway secretions studied by the PCR panel. For every virus examined, the positive PCR control showed an unequivocal band of predicted size, while negative control specimens showed no evidence of contamination. In all specimens, the GAPDH gene was amplified by PCR, indicative of successful nucleic acid extraction and the absence of PCR inhibitors. The number of positive clinical specimens was highly variable, ranging from six of 10 in influenza A to zero of 10 for influenza C and coronaviruses 229E and OC43.

Nucleic acid from at least one virus was detected in 19 of 20 specimens and from more than one virus in 14 of 20 specimens. The viral nucleic acids identified most frequently were RSV in 13 of 20 cases, influenza A in 11 of $20, \mathrm{HRV}$ in seven 
TABLE 3

Viral nucleic acid identified by polymerase chain reaction (PCR)

\begin{tabular}{lcccc}
\hline Virus PCR (+) & Fatal asthma & Nonfatal asthma & Nonasthma controls & P \\
\hline Human rhinovirus & $3 / 10$ & $2 / 4$ & $2 / 6$ & NS* \\
Respiratory syncytial virus & $7 / 10$ & $2 / 4$ & $4 / 6$ & $\mathrm{NS}$ \\
Influenza A & $5 / 10$ & $2 / 4$ & $4 / 6$ & $\mathrm{NS}$ \\
Influenza B & $1 / 10$ & $2 / 4$ & $0 / 6$ & $\mathrm{NS}$ \\
Influenza C & $0 / 10$ & $1 / 4$ & $0 / 6$ & $\mathrm{NS}$ \\
Coronavirus 229E & $1 / 10$ & $0 / 4$ & $0 / 6$ & $\mathrm{NS}$ \\
Coronavirus OC43 & $0 / 10$ & $0 / 4$ & $1 / 6$ & $\mathrm{NS}$ \\
Parainfluenza virus & $0 / 10$ & $0 / 4$ & $2 / 6$ & $\mathrm{NS}$ \\
Adenovirus & $1 / 10$ & $2 / 4$ & & \\
\hline
\end{tabular}

${ }^{\star} P>0.05$. NS Not significant

of 20 and influenza B in six of 20. No significant difference in the prevalence of viral nucleic acid, either singly or in combination, was present among groups of patients (Table 3). There was no relationship between the number and types of viruses identified by PCR, and the severity of asthma, smoking status, or date or place of death. None of the cases or controls showed histopathological features consistent with active bacterial or fungal infection, and no viral inclusions were identified.

\section{DISCUSSION}

The results of this study are based on the application of a panel of PCR protocols used to document the prevalence of nucleic acid of common respiratory viruses in the intraluminal contents of the airways collected at postmortem examination. The specimens were obtained from cases where asthma was the cause of death and deaths from other causes where the person either did or did not have asthma. The results show a similar prevalence of nucleic acid from these pathogens among the three groups studied. No particular virus or combination of viruses was specific to fatal asthma.

The specimens obtained for analysis came directly from the lower airways after the lung had been removed from the thorax at autopsy to minimize the potential for upper airway contamination. Because these viral PCR results are similar to the results of our preliminary study of viral nucleic acid detection in surgically resected lung specimens (15), it is unlikely that specimens of lower airway secretions were contaminated by pathogens from the upper respiratory tract. A PCR-based panel for detection of viral nucleic acid was used because it provided a sensitive, practical way to screen for large numbers and serotypes of the nine viruses examined. Previous work using a similar three-virus PCR panel (14) showed that PCR results correlated well with the results of viral culture, although there was a clear tendency for the PCR technique to detect a greater number of simultaneous infections than culture. In addition, PCR detected viral nucleic acid in specimens in which no replicating viruses could be isolated by culture.

Previous studies that used culture to document viral respiratory tract infections have reported that the shedding of common respiratory viruses from the upper airways lasts for approximately five to seven days after the onset of clinical symptoms, with apparent complete clearance from the respiratory tract during convalescence (19). However, because the PCR-based techniques used in this study were more sensitive than culture, the viral nucleic acids detected by PCR might have been related to latent or persistent infections. Although there is only limited information about the possible persistence of common respiratory viruses in the lower respiratory tract of humans (20), animal studies have clearly shown that RSV can be isolated by culture in lung homogenates from experimentally infected guinea pigs for at least two months after the viral inoculation (21). In addition, the RSV genome can be detected in the lungs of guinea pigs for at least four months after experimental inoculation (22). Latent adenoviral infection of the guinea pig lung has also been reported by using PCR-based methods of viral detection (23). The similar prevalence of viral nucleic acid in the three groups studied is consistent with the hypothesis that human lung tissue may serve as a reservoir for common respiratory viruses. Characterizing the nature of such a reservoir may provide new insights into virus-host interactions and the pathogenesis of viral respiratory tract infections.

\section{CONCLUSIONS}

The results of this study show a high prevalence of nucleic acid from common respiratory viruses in the intraluminal secretions of the lower airways. Owing to the precautions taken at postmortem examination and during subsequent specimen handling, as well as by obtaining similar PCR results to those obtained from surgically resected lung specimens (15), we believe that the viral nucleic acid detected in these secretions did not result from contamination. Overall, the similar prevalence of these viruses in the lower airway secretions obtained from autopsy cases of fatal asthma, nonfatal asthma and nonasthmatic controls make it difficult to implicate viral infection in acute asthmatic deaths. Intriguingly, the results suggest the hypothesis that the lower respiratory tract may serve as a reservoir for many viruses that may become latent (persisting viral DNA without replication) or survive by low-level replication, in the case of RNA viruses. 
ACKNOWLEDGEMENTS: We thank H Ahmad for technical assistance with polymerase chain reaction experiments, and S Greene for expert assistance in photography. This work was supported by the Medical Research Council of Canada, Ottawa, Ontario (MT7246 and MT-13766), Respiratory Health Network of Centres of Excellence, Health Canada, and The Herron Foundation of Alberta, Calgary, Alberta. Dr Hegele is the recipient of a British Columiba Lung Association/Medical Research Council of Canada Scholarship Award. The cases examined in this study originated from the following centres: Office of the Medical Examiner, Calgary, Alberta (eight cases); Foothills Hospital, Calgary, Alberta (two cases); Office of the Medical Examiner, Edmonton, Alberta (four cases); Bonneville Medical Centre, Cold Lake, Alberta (two cases); Lethbridge Regional Hospital, Lethbridge, Alberta (one case); Pasqua Hospital, Regina, Saskatchewan (two cases); and St Boniface Hospital, Winnipeg, Manitoba (one case).

\section{REFERENCES}

1. Johnston SL, Pattemore PK, Sanderson G, et al. Community study of role of viral infections in exacerbations of asthma in 9-11 year old children. Br Med J 1995;310:1225-9.

2. Nicholson KG, Kent J, Ireland DC. Respiratory viruses and exacerbations of asthma in adults. Br Med J 1993;307:982-6.

3. Pattemore PK, Johnston SL, Bardin PG. Viruses as precipitants of asthma symptoms. I. Epidemiology. Clin Exp Allergy 1992;22:325-36.

4. Thomas LH, Fraenkel DJ, Bardin PG, Johnston SL, Holgate ST, Warner JA. Leukocyte responses to experimental infection with human rhinovirus. J Allergy Clin Immunol 1994;94:1255-62.

5. Cheung D, Dick EC, Timmers MC, de Klerk EPA, Spaan WJM, Sterk PJ. Rhinovirus infection causes long-lasting excessive airway narrowing in response to methacholine in asthmatic subjects in vivo. Am J Respir Crit Care Med 1995;152:1490-6.

6. Gern JE, Galagan DM, Jarjour NN, Dick EC, Busse WW. Detection of rhinovirus RNA in lower airway cells during experimentally induced infection. Am J Respir Crit Care Med 1997;155:1159-61.

7. Folkerts G, Busse WW, Nijkamp FP, Sorkness R, Gern JE. Virus-induced airway hyperresponsiveness and asthma. Am J Respir Crit Care Med 1998;157:1708-20.

8. Faul JL, Tormey VJ, Leonard C, et al. Lung immunopathology in cases of sudden asthma death. Eur Respir J 1997;10:301-7.
9. Whitton JL, Oldstone MBA. Immune response to viruses. In: Fields BN, Knipe DM, Howley PM, et al, eds. Fields Virology, 3rd edn. Philadelphia: Lippincott-Raven Publishers, 1996:345-74.

10. Donofrio JC, Coonrod D, Davidson JN, Betts RF. Detection of influenza $\mathrm{A}$ and $\mathrm{B}$ in respiratory secretions with the polymerase chain reaction. PCR Methods Appl 1992;1:263-8.

11. Johnston SL, Sanderson G, Pattemore PK, et al. Use of polymerase chain reaction for diagnosis of picornavirus infection in subjects with and without respiratory symptoms. J Clin Microbiol 1993;31:111-7.

12. Myint S, Johnston S, Sanderson G, Simpson H. Evaluation of nested polymerase chain reaction methods for the detection of human coronaviruses 229E and OC43. Mol Cell Probes 1994;8:357-64.

13. Puig M, Jofre J, Lucena F, Allard A, Wadell G, Girones R. Detection of adenoviruses and enteroviruses in polluted water by nested PCR amplification. Appl Environ Microbiol 1994;60:2963-70.

14. Gilbert LL, Dakhama A, Bone BM, Thomas EE, Hegele RG. Diagnosis of viral respiratory tract infections in children by using a reverse transcription-polymerase chain reaction (RT-PCR) panel. J Clin Microbiol 1996;34:140-3.

15. Hogg JC, Macek V, Dakhama A, Hayashi S, Hegele RG. The prevalence of common respiratory viruses in human lungs. In: Marone G, Austen KF, Holgate ST, Kay AB, Lichtenstein LM, eds. Asthma and Allergic Diseases. Physiology, Immunopharmacology, and Treatment. San Diego: Academic Press, 1998:321-33.

16. Dakhama A, Macek V, Hogg JC, Hegele RG. Amplification of human-actin gene by the reverse transcriptase-polymerase chain reaction: implications for assessment of RNA from formalin-fixed, paraffin-embedded material. J Hisotchem Cytochem 1996;44:1205-7.

17. Tough S, Green FH, Paul JE, Wigle DT, Butt JC. Sudden death from asthma in 108 children and young adults. J Asthma 1996;33:179-88.

18. Dunnill MS. The pathology of asthma, with special reference to changes in the bronchial mucosa. J Clin Pathol 1960;13:27-33.

19. Walker TA, Khurana S, Tilden SJ. Viral respiratory infections. Pediatr Clin North Am 1994;41:1365-78.

20. Matsuse T, Hayashi S, Kuwano K, Keunecke H, Jefferies WA, Hogg JC. Latent adenoviral infection in the pathogenesis of chronic airways obstruction. Am Rev Respir Dis 1992;746:177-84.

21. Dakhama A, Vitalis TZ, Hegele RG. Persistence of respiratory syncytial virus (RSV) and development of RSV-specific IgG1 antibodies in a guinea pig model of acute bronchiolitis. Eur Respir J 1997; 10:20-6.

22. Hegele RG. The role of viruses in chronic respiratory disease. Clin Pulmonol Med 1996;3:185-90.

23. Vitalis TZ, Keicho N, Itabashi S, Hayashi S, Hogg JC. A model of latent adenovirus 5 infection on the guinea pig (Cavia porcellus). Am J Respir Cell Mol Biol 1996;14:225-31. 


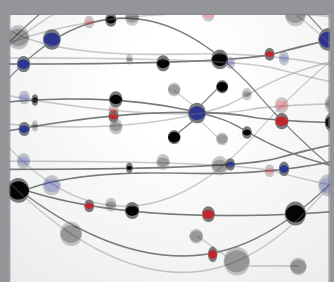

The Scientific World Journal
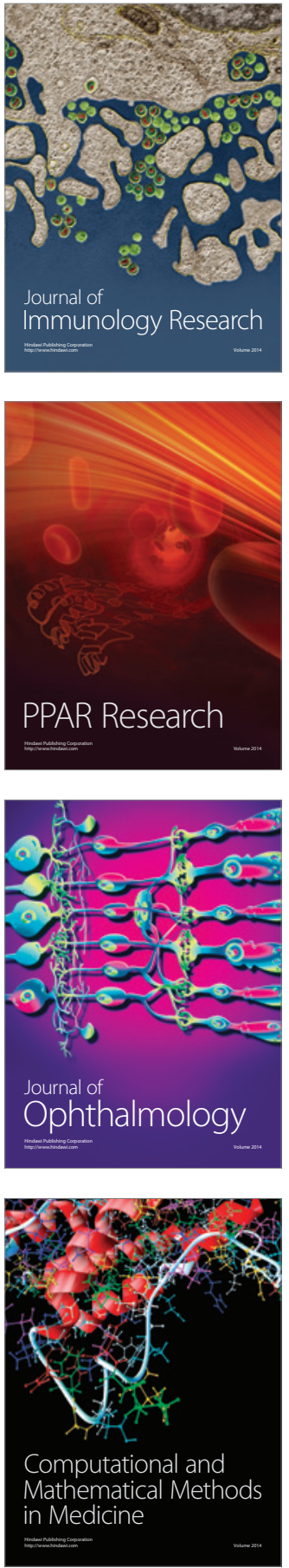

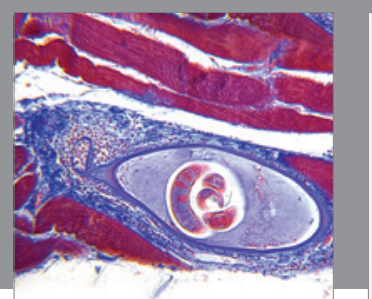

Gastroenterology Research and Practice

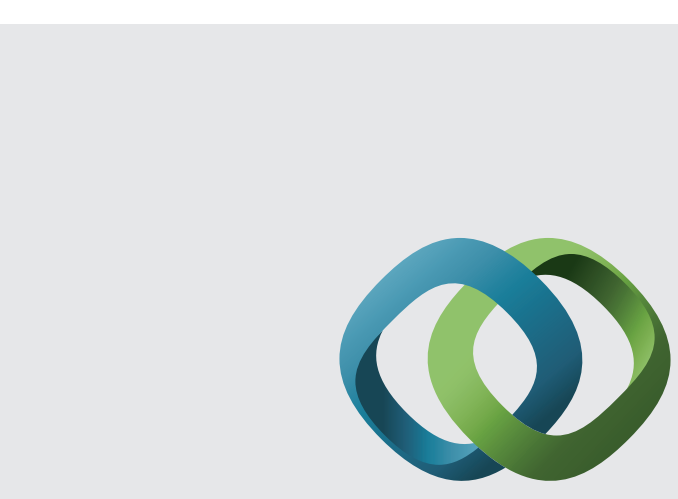

\section{Hindawi}

Submit your manuscripts at

http://www.hindawi.com
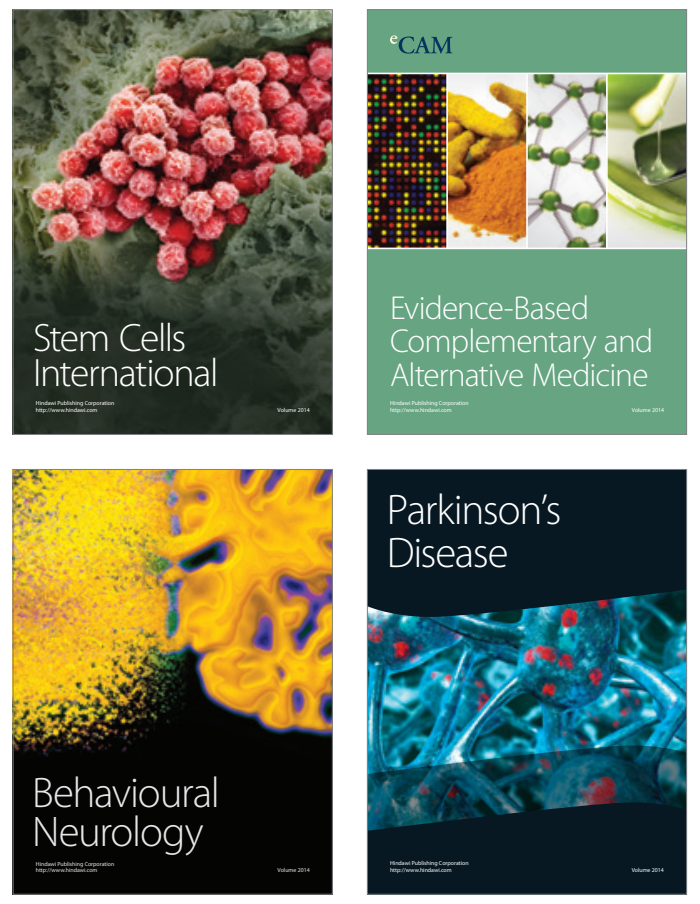
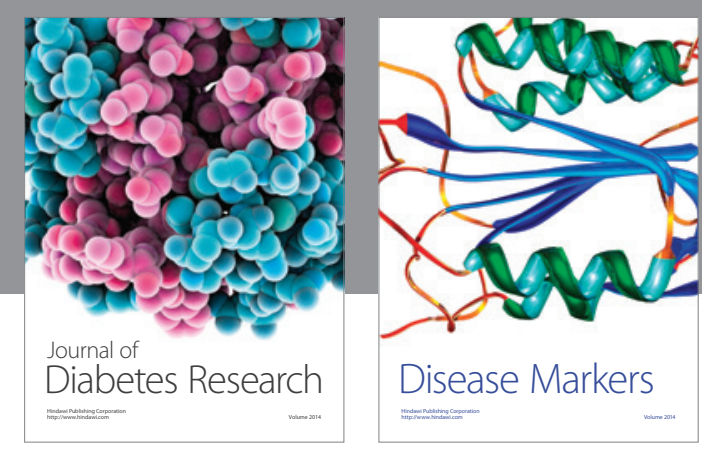

Disease Markers
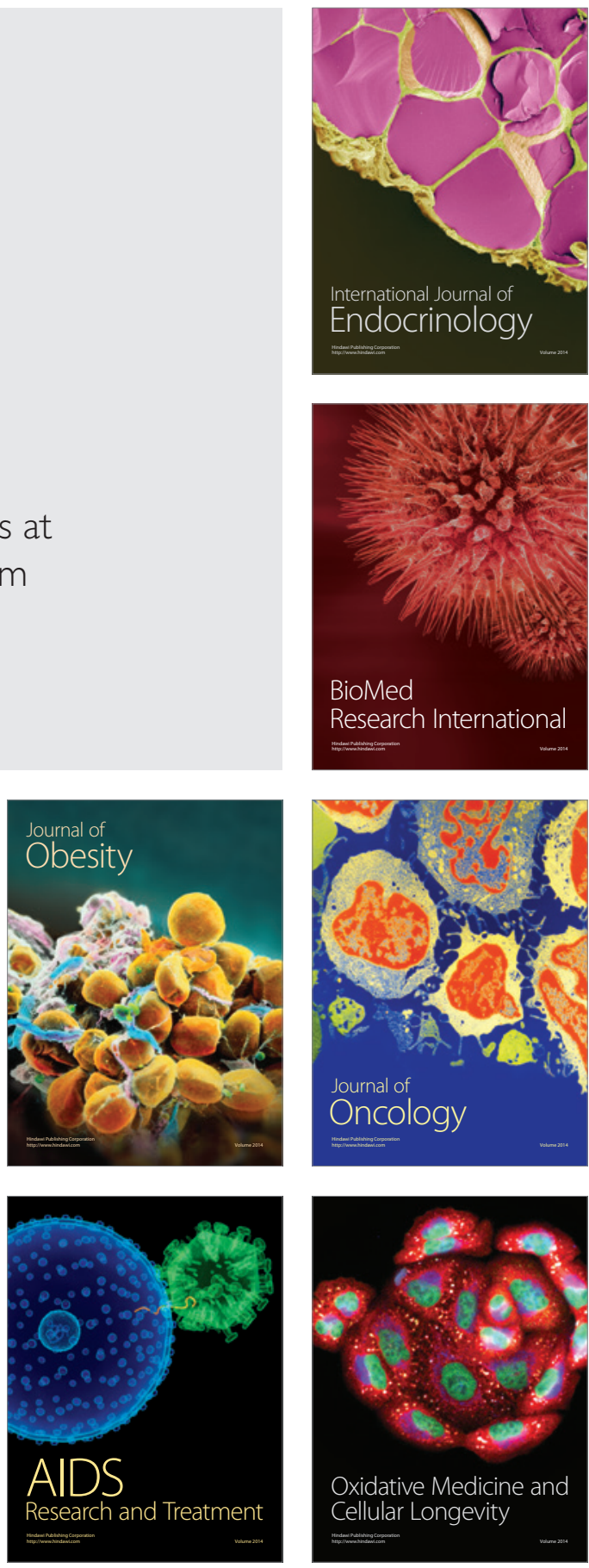